\section{Bell Pepper Cultivar Performance under Short, Variable Growing Seasons}

\author{
Mark G. Hutton ${ }^{1,3}$ and David T. Handley ${ }^{2}$
}

AdDITIONAL INDEX wORDs. Capsicum annunm, fruit size, yield

Summary. Twenty-seven green bell pepper (Capsicum annuum) cultivars were evaluated over three growing seasons in Maine. Each year, plants started in a greenhouse were transplanted into double rows on raised beds covered with black plastic mulch. Overall yields were low compared with similar experiments in other regions of North America and varied considerably from year to year. 'Ace' and 'New Ace' consistently produced the largest crops by both weight and number of fruit. However, both of these cultivars had undesirable characteristics of small fruit size $(<150 \mathrm{~g})$, few lobes (two-three), and thin fruit walls $(<6 \mathrm{~mm})$, limiting their commercial market potential. Other cultivars, including 'Vivaldi', 'Patriot', and 'Socrates', had significantly better fruit quality but very low or inconsistent yield. The results of this study demonstrate the current limitations for growing economically viable crops of bell peppers in regions such as Maine that have short growing seasons and a wide range of seasonal temperatures. Further, the data underline the need for the development of cultivars better adapted to these growing conditions.

$\mathrm{I}_{\mathrm{i}}^{\mathrm{n}}$ n Maine and other parts of the northeastern United States, there is a consistent, strong market demand for high-quality, locally grown bell peppers. However, optimal temperatures for pepper production are between 60 to $80{ }^{\circ} \mathrm{F}$ (Maynard and Hochmuth, 1997), and open flowers are prone to abortion under cool nights with temperatures below $50{ }^{\circ} \mathrm{F}$ (Wien, 1997). The growing season in Maine is short and cool with great fluctuations in temperature. Temperatures below $50{ }^{\circ} \mathrm{F}$ and over $80{ }^{\circ} \mathrm{F}$ are not uncommon and can often occur within a 24 -h period (Fig. 1). This makes bell peppers challenging to grow in this region.

Although use of season extension technologies such as plastic mulch and rowcovers are common throughout the region to warm the

Maine Agricultural and Forestry Experiment Station publication number 2920.

This work funded in part by CSREES/USDA, the Maine Vegetable and Small Fruit Growers Association, and the New England Vegetable and Berry Growers Association.

Mention of a trademark, proprietary product, or vendor does not constitute a guarantee or warranty of the product, nor does it imply approval or disapproval to the exclusion of other products or vendors.

${ }^{1}$ Department of Plant, Soil and Environmental Science, and University of Maine Cooperative Extension, Highmoor Farm, P.O. Box 179, Monmouth, ME 04259 .

${ }^{2}$ University of Maine Cooperative Extension, Highmoor Farm, P.O. Box 179, Monmouth, ME 04259 .

${ }^{3}$ Corresponding author. E-mail: mhutton@umext. maine.edu soil and increase the temperature in the environment directly near the plant (Wells and Loy, 1985), these technologies have not been able to completely overcome the area's climatic disadvantages. Selection of cultivars that can produce good yields of high-quality bell peppers under these relatively difficult conditions is essential for the commercial success of this crop in northern climates. The objective of this research was to identify cultivars that will produce consistently large yields in a northern climate and to evaluate the characteristics of the harvested fruit to make recommendations for this region.

\section{Materials and methods}

Pepper cultivar trials were conducted at the University of Maine Agricultural and Forest Experiment Station at Highmoor Farm in Monmouth (lat. $42.2^{\circ} \mathrm{N}$, long. $72.1^{\circ} \mathrm{W}$ ). A total of 27 commercially available cultivars were evaluated over 3 years, from 2003 to 2005 (Table 1). Eight cultivars were grown in all 3 years, seven cultivars were grown in 2 years, and 12 cultivars were grown in only 1 year.

All plants were started from seed in greenhouse trays $23 / 4 \times 14 \times$ 20 inches with drain holes (Dyna-flat; Hummert International, Earth City, Mo.) filled with soilless plug mix (Redi-Earth Plug and Seedling Mix; SunGro Horticulture, Vancouver, B.C.). Seeding dates were 23 Apr. 2003, 28 Apr. 2004, and 22 Apr. 2005. The trays were placed on soil heating mats at $85{ }^{\circ} \mathrm{F}$. When the cotyledons were fully expanded and the first true leaf just showing, healthy individual seedlings were transplanted into trays filled with soilless plug mix. The trays were placed on benches in a greenhouse, held at $67^{\circ} \mathrm{F}$, and watered as needed. Two weeks after transplanting into the trays, the plants were root pruned by cutting the soil into blocks $\approx 1.5 \times$ 2.0 inches. The plants were root pruned a second time before transfer to a coldframe for hardening off. The plants were hardened off for $3 \mathrm{~d}$ before planting in the field.

The plants were transplanted to the field on 9 June 2003, 15 June 2004, and 15 June 2005, respectively. The field had been broadcast fertilized with $500 \mathrm{lb} /$ acre of $10 \mathrm{~N}-$ $4.4 \mathrm{P}-8.3 \mathrm{~K}$ according to soil test recommendations. Three replicates of each cultivar were transplanted by hand in a randomized completeblock design. Each plot consisted of 20 plants planted in double rows on black plastic polyethylene mulch covered beds $4 \mathrm{ft}$ wide and spaced $6 \mathrm{ft}$ apart. Plant spacing within and between rows was 18 inches. The plants received $16 \mathrm{fl} \mathrm{oz}$ of $8 \mathrm{~N}-19.7 \mathrm{P}-11.6 \mathrm{~K}$ starter fertilizer (Peters Professional; The Scotts Co., Marysville, Ohio) at transplanting. No supplemental irrigation was supplied in this study. Less than $33 \%$ of mixed vegetable growers in Maine use irrigation (U.S. Dept. of Agriculture, 2004). No insecticide or fungicides

\begin{tabular}{llll}
\hline $\begin{array}{l}\text { Units } \\
\text { To convert U.S. to SI, } \\
\text { multiply by }\end{array}$ & U.S. unit & SI unit & $\begin{array}{l}\text { To convert SI to U.S., } \\
\text { multiply by }\end{array}$ \\
\hline 29.5735 & $\mathrm{fl} \mathrm{oz}$ & $\mathrm{mL}$ & 0.0338 \\
0.3048 & $\mathrm{ft}$ & $\mathrm{m}$ & 3.2808 \\
2.54 & inch $(\mathrm{es})$ & $\mathrm{cm}$ & 0.3937 \\
25.4 & inch(es) & $\mathrm{mm}$ & 0.0394 \\
0.4536 & $\mathrm{lb}$ & $\mathrm{kg}$ & 2.2046 \\
28.3495 & $\mathrm{Oz}$ & $\mathrm{g}$ & 0.0353 \\
$\left({ }^{\circ} \mathrm{F}-32\right) \div 1.8$ & ${ }^{\circ} \mathrm{F}$ & ${ }^{\circ} \mathrm{C}$ & $\left(1.8 \times{ }^{\circ} \mathrm{C}\right)+32$
\end{tabular}



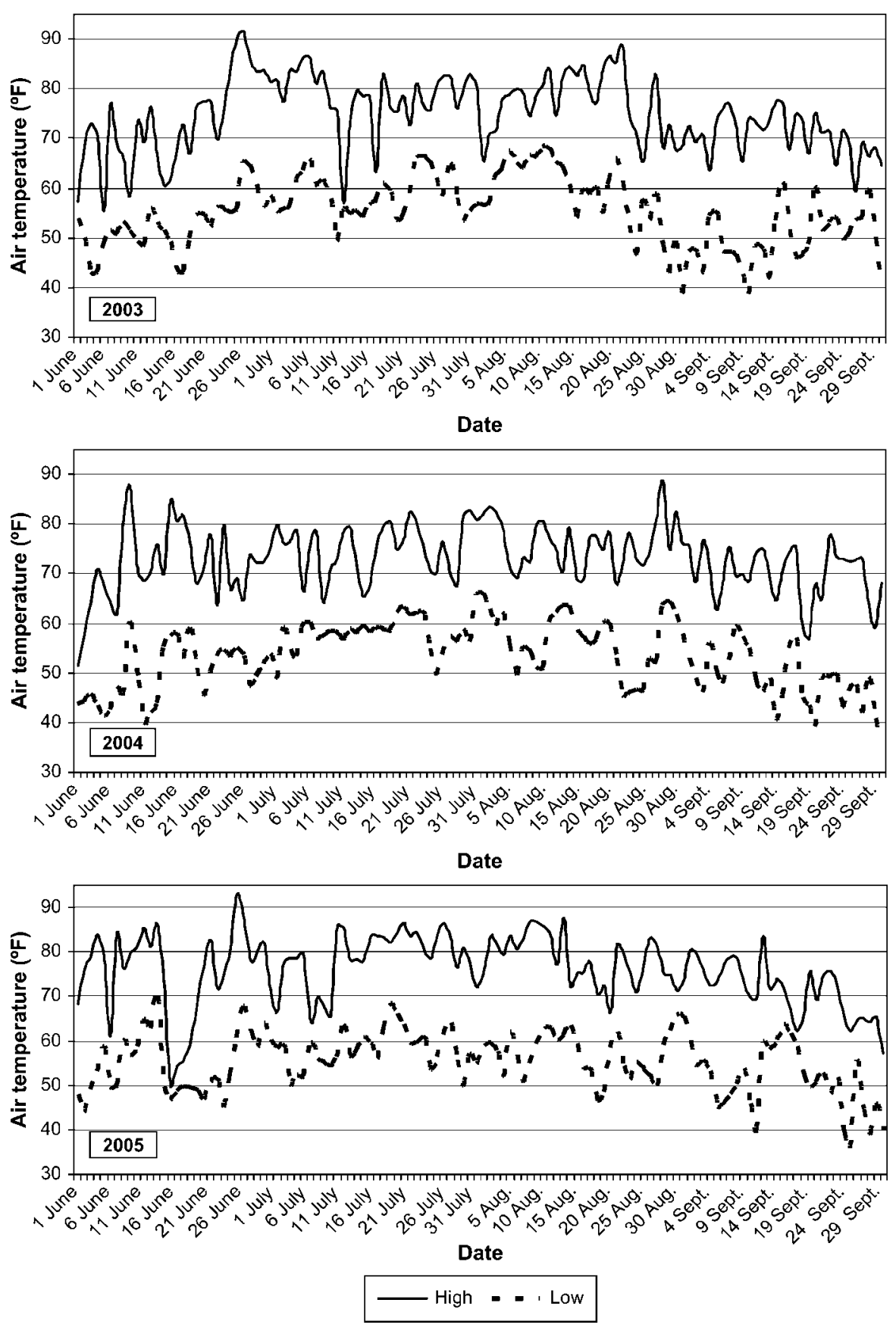

Fig. 1. Daily high and low temperatures during the 2003, 2004, and 2005 growing seasons in Monmouth; $\left({ }^{\circ} \mathrm{F}-32\right) / 1.8={ }^{\circ} \mathrm{C}$.

were applied to evaluate potential problems. Weeds were managed by cultivation.

Plants were harvested from 18 Aug. to 26 Sept. 2003, 18 Aug. to 23 Sept. 2004, and 18 Aug. to 16 Sept. 2005. A total of four harvests were made in 2003, seven in 2004, and six in 2005. The center 16 plants of each double-row plot were harvested; the two plants at each end of the plot served as guard plants to the adjoining plots. The number of marketable
(Campbell Scientific, Logan, Utah). Air temperature was measured with a Type $T$, copper-constantin thermocouple, placed $4 \mathrm{ft}$ aboveground inside the weather station case. Rainfall was measured in increments of 0.01 inch using a rain gauge (model 6021-A; Qualimetrics, Sacramento, Calif.)

During each of the 3 years, total number and weight of marketable fruit per plot and the number and weight of cull fruit per plot were collected. These data were subjected to analysis of variance and mean separation using least significant difference (LSD) test at $P=0.05$.

\section{Results and discussion}

Weather over the 3 years was typical for Maine, with average temperatures ranging from 59 to $68^{\circ} \mathrm{F}$ (Table 2). Large changes in daily temperature occurred throughout the growing season (Fig. 1). The temperatures in 2004 were slightly more moderate compared with 2003 and 2005 , with warmer minimum temperatures and cooler maximum temperatures. Rainfall in each year was about 20 inches over the 4-month period, although the monthly distribution differed in each year. In 2003, most of the rain came toward the end of the growing season in August and September. July and August were the wettest months in 2004.

Yield data varied over the 3 years of this trial, both between cultivars and within the cultivars that were represented each year (Table 3 ). Yield of marketable fruit was much lower in 2003,17 fruit per plot averaged overall cultivars compared with 50 fruit per plot in 2004 and 37 fruit per plot in 2005. In 2004, the number of harvested fruit of many cultivars was much higher (often more than double) than in 2003 or 2005 . The weight of marketable yield averaged overall cultivars was similar in 2004 $(5.4 \mathrm{~kg})$ and $2005(5.6 \mathrm{~kg})$. The amount of cull fruit was greatest in 2004. Moderate temperatures and more spring rainfall may have contributed to the increased fruit set occurring in 2004 (Table 2).

Compared with the results of trials in other regions of North America, bell pepper yields in this trial were low (Table 3). Similar studies in Ontario (Zandstra and Squire, 2004) and Kentucky (Rowell et al., 2001) reported yields more than four times 
Table 1. Partial 2003-2005 weather summary for University of Maine, Highmoor Farm, in Monmouth.

\begin{tabular}{lcccc}
\hline Month & $\begin{array}{c}\text { Avg temp } \\
\left({ }^{\circ} \mathbf{F}\right)^{\mathbf{z}}\end{array}$ & $\begin{array}{c}\text { Minimum } \\
\text { temp }\left({ }^{\circ} \mathbf{F}\right)\end{array}$ & $\begin{array}{c}\text { Maximum } \\
\text { temp }\left({ }^{\circ} \mathbf{F}\right)\end{array}$ & $\begin{array}{c}\text { Total precipitation } \\
\text { (inches) }\end{array}$ \\
\hline June & & & 2003 & \\
July & 63 & 43 & 92 & 4.0 \\
August & 68 & 49 & 86 & 3.0 \\
September & 68 & 39 & 89 & 5.0 \\
& 60 & 39 & 78 & 8.2 \\
June & 61 & 40 & $\mathbf{2 0 0 4}$ & 3.6 \\
July & 66 & 49 & 88 & 6.9 \\
August & 66 & 46 & 89 & 8.9 \\
September & 59 & 37 & 78 & 3.7 \\
& & & 2005 & 5.8 \\
June & 65 & 44 & 93 & 3.6 \\
July & 68 & 50 & 87 & 7.5 \\
August & 68 & 46 & 88 & 4.1 \\
September & 61 & 36 & 84 & \\
\hline
\end{tabular}

${ }^{\mathrm{z}}\left({ }^{\circ} \mathrm{F}-32\right) \div 1.8={ }^{\circ} \mathrm{C}$

y 1 inch $=25.4 \mathrm{~mm}$.

higher than those observed from this trial. In addition to wide temperature fluctuations observed, other factors may have contributed to the low yields observed (i.e., low fertility, lack of irrigation at critical times, etc.).

Among the cultivars tested in all 3 years of the trial, 'Ace' was the most

Table 2. Year and cultivar combinations of bell peppers grown at the University of Maine, Highmoor Farm, in Monmouth.

\begin{tabular}{|c|c|c|c|c|}
\hline \multirow[b]{2}{*}{ Cultivar } & \multirow[b]{2}{*}{ Source $^{\mathrm{z}}$} & \multicolumn{3}{|c|}{ Year } \\
\hline & & 2003 & 2004 & 2005 \\
\hline Ace & Johnny's & $\mathrm{X}$ & $\mathrm{X}$ & $\mathrm{X}$ \\
\hline Brigadier & Seigers & $\mathrm{x}$ & $\mathrm{X}$ & $\mathrm{X}$ \\
\hline Double-Up & Seedway & $\mathrm{x}$ & $\mathrm{X}$ & $\mathrm{X}$ \\
\hline King Arthur & Seedway & $\mathrm{X}$ & $\mathrm{X}$ & $\mathrm{X}$ \\
\hline New Ace & Harris & $\mathrm{X}$ & $\mathrm{X}$ & $\mathrm{X}$ \\
\hline Patriot & Harris & $\mathrm{x}$ & $\mathrm{x}$ & $\mathrm{x}$ \\
\hline Socrates & Stokes & $\mathrm{x}$ & $\mathrm{x}$ & $\mathrm{x}$ \\
\hline Vivaldi & Seedway & $\mathrm{X}$ & $\mathrm{X}$ & $\mathrm{X}$ \\
\hline Aristotle X3R & Harris & $\mathrm{X}$ & & $\mathrm{x}$ \\
\hline Early Sunsation & Harris & $\mathrm{X}$ & $\mathrm{X}$ & \\
\hline Boyton Bell & Harris & & $\mathrm{X}$ & $\mathrm{X}$ \\
\hline Lady Bell & Harris & & $\mathrm{x}$ & $\mathrm{X}$ \\
\hline Red Knight & Siegers & & $\mathrm{X}$ & $\mathrm{x}$ \\
\hline Sweet Chocolate & Johnny's & & $\mathrm{x}$ & $\mathrm{x}$ \\
\hline Yankee Bell & Johnny's & & $\mathrm{X}$ & $\mathrm{X}$ \\
\hline Alliance & Stokes & & & $\mathrm{x}$ \\
\hline Excel & Siegers & & & $\mathrm{x}$ \\
\hline Gourmet & Johnny's & $\mathrm{X}$ & & \\
\hline Heritage & Harris & $\mathrm{x}$ & & \\
\hline Ironsides & Siegers & $\mathrm{x}$ & & \\
\hline Olympus & Seedway & $\mathrm{x}$ & & \\
\hline Queen & Siegers & $\mathrm{X}$ & & \\
\hline Karma & Harris & & $\mathrm{X}$ & \\
\hline North Star & Rupp & & & $\mathrm{X}$ \\
\hline Orion & Johnny's & & & $\mathrm{x}$ \\
\hline Revolution & Harris & & & $\mathrm{x}$ \\
\hline Telstar & Siegers & & & $\mathrm{x}$ \\
\hline
\end{tabular}

productive in terms of fruit number and total marketable yield in 2003 , and ranked among the three highest in 2004 and 2005 (Table 3). 'New Ace' was also a consistently highyielding cultivar in this study. 'New Ace' was the highest-yielding cultivar in 2005, although not significantly greater than 'Ace' or 'Vivaldi'. In 2003, with the exception of 'Ace', 'New Ace', and 'Vivaldi', none of the other cultivars tested produced more than one fruit per plant, and were not considered economically viable in that season. In 2004, 'Double-Up' and 'Patriot' ranked among the top five cultivars for fruit number, but they were not significantly greater than 'Socrates', 'King Arthur', 'Brigadier' or 'Vivaldi'. Only 'Vivaldi' produced enough fruit by weight to be ranked among the top five cultivars. In 2005, 'Vivaldi' ranked among the top five yielding cultivars for both fruit number and weight. 'Socrates', 'King Arthur', and 'Double-Up' fell into the middle of the range for yield, while 'Brigadier' and 'Patriot' again produced unacceptable yields of less than one fruit per plant.

Among the entries that were evaluated in two seasons of the trial, 'Sweet Chocolate' appeared to be the most promising, being among the highest three cultivars for fruit number and weight in both 2004 and 2005. 'Lady Bell' produced consistent, relatively high yields in the 2 years it was evaluated (2004, 2005 ), but its productivity was significantly lower than the top-yielding cultivars 'Ace' and 'New Ace' in both years. Additionally, the only incidence of bacterial leaf spot (Xanthomonas campestris pv. vesicatoria) observed in the 3 years of this study occurred on 'Lady Bell' in 2004. Although yields of 'Early Sunsation' were too low in 2003 to be considered economically viable, it ranked in the upper middle of the range for fruit number and weight in 2003 and 2004. 'Aristotle' (in 2003 and 2005), 'Boynton Bell' (in 2004 and 2005), 'Red Knight' (in 2004 and 2005), and 'Yankee Bell' (in 2004 and 2005 ) yielded inconsistently over the 2 years they were evaluated, performing in the middle to upper middle of the range in 1 year, and in the lower end of the range in another.

Among the cultivars that were evaluated in only 1 year of the trial, 
Table 3. Average of marketable fruit, marketable fruit weight, cull number, and cull fruit weight per plot $^{\mathrm{z}}$ of bell peppers grown in 2003-2005 at the University of Maine, Highmoor Farm, in Monmouth.

\begin{tabular}{|c|c|c|c|c|}
\hline Cultivar & $\begin{array}{c}\text { Marketable } \\
\text { fruit } \\
\text { (no.) }\end{array}$ & $\begin{array}{c}\text { Marketable } \\
\text { fruit } \\
(\mathrm{kg})^{\mathrm{y}}\end{array}$ & $\begin{array}{c}\text { Cull fruit } \\
\text { (no.) }\end{array}$ & $\begin{array}{c}\text { Cull fruit } \\
(\mathrm{kg})\end{array}$ \\
\hline & \multicolumn{4}{|c|}{2003} \\
\hline Ace & 77.0 & $11.60 \mathrm{a}$ & 1.3 & 0.21 \\
\hline New Ace & $60.3 \mathrm{~b}$ & $9.47 \mathrm{~b}$ & 2.7 & 0.41 \\
\hline Vivaldi & $27.7 \mathrm{c}$ & $5.72 \mathrm{c}$ & 1.0 & 0.21 \\
\hline Aristotle X3R & $18.0 \mathrm{~d}$ & $3.44 \mathrm{~d}$ & 0.3 & 0.08 \\
\hline Double-Up & $14.7 \mathrm{de}$ & $2.26 \mathrm{de}$ & 0.7 & 0.19 \\
\hline Early Sunsation & $12.0 \mathrm{~d}-\mathrm{f}$ & $2.46 \mathrm{de}$ & 0.0 & 0.00 \\
\hline Patriot & $10.3 \mathrm{~d}-\mathrm{g}$ & $2.40 \mathrm{de}$ & 0.3 & 0.15 \\
\hline King Arthur & $10.0 \mathrm{~d}-\mathrm{g}$ & $1.94 \mathrm{~d}-\mathrm{f}$ & 0.3 & 0.09 \\
\hline Brigadier & $9.7 \mathrm{~d}-\mathrm{g}$ & $2.28 \mathrm{de}$ & 0.7 & 0.18 \\
\hline Ironsides & $8.7 \mathrm{e}-\mathrm{g}$ & $1.82 \mathrm{~d}-\mathrm{f}$ & 0.0 & 0.00 \\
\hline Olympus & $6.3 \mathrm{e}-\mathrm{g}$ & $1.58 \mathrm{ef}$ & 0.0 & 0.00 \\
\hline Queen & $6.0 \mathrm{fg}^{\circ}$ & $1.19 \mathrm{ef}$ & 1.0 & 0.17 \\
\hline Socrates & $6.0 \mathrm{fg}$ & $1.79 \mathrm{~d}-\mathrm{f}$ & 0.7 & 0.19 \\
\hline Heritage & $5.7 \mathrm{fg}$ & $1.45 \mathrm{ef}$ & 0.3 & 0.06 \\
\hline Gourmet & $3.0 \mathrm{~g}$ & $0.58 \mathrm{f}$ & 1.7 & 0.31 \\
\hline \multirow[t]{2}{*}{$\operatorname{LSD}(P=0.05)^{\mathrm{x}}$} & $8.4^{\circ}$ & 1.67 & NS & NS \\
\hline & \multicolumn{4}{|c|}{2004} \\
\hline Ace & $128.3 \mathrm{a}$ & $9.50 \mathrm{ab}$ & 58.7 & 4.57 \\
\hline New Ace & $118.3 \mathrm{a}$ & $10.69 \mathrm{a}$ & 62.3 & 5.74 \\
\hline Sweet Chocolate & $100.0 \mathrm{a}$ & $7.92 \mathrm{a}-\mathrm{c}$ & 83.7 & 4.41 \\
\hline Lady Bell & $60.0 \mathrm{~b}$ & $5.99 \mathrm{~b}-\mathrm{d}$ & 35.0 & 3.56 \\
\hline Double-Up & $41.7 \mathrm{bc}$ & $4.20 \mathrm{~d}$ & 39.7 & 3.93 \\
\hline Patriot & $40.3 \mathrm{bc}$ & $4.05 \mathrm{~d}$ & 43.7 & 3.28 \\
\hline Boyton Bell & $36.7 \mathrm{bc}$ & $4.63 \mathrm{~cd}$ & 60.0 & 3.24 \\
\hline Early Sunsation & $35.0 \mathrm{bc}$ & $4.21 \mathrm{~d}$ & 44.3 & 2.98 \\
\hline Red Knight & $33.7 \mathrm{bc}$ & $4.39 \mathrm{~cd}$ & 35.3 & 3.83 \\
\hline Socrates & $32.7 \mathrm{bc}$ & $3.56 \mathrm{~d}$ & 26.3 & 3.05 \\
\hline King Arthur & $31.7 \mathrm{bc}$ & $4.55 \mathrm{~cd}$ & 35.3 & 3.34 \\
\hline Brigadier & $31.3 c$ & $5.91 \mathrm{~cd}$ & 21.3 & 2.78 \\
\hline Vivaldi & $27.3 \mathrm{c}$ & $6.10 \mathrm{~b}-\mathrm{d}$ & 52.0 & 3.93 \\
\hline Yankee Bell & $25.0 \mathrm{c}$ & $3.82 \mathrm{~d}$ & 52.7 & 3.03 \\
\hline Karma & $23.0 \mathrm{c}$ & $3.18 \mathrm{~d}$ & 44.3 & 3.09 \\
\hline \multirow[t]{2}{*}{$\operatorname{LSD}(P=0.05)$} & 28.5 & 3.57 & NS & NS \\
\hline & \multicolumn{4}{|c|}{2005} \\
\hline New Ace & $86.3 \mathrm{a}$ & $11.95 \mathrm{a}$ & $12.7 \mathrm{bc}$ & $1.45 \mathrm{~b}-\mathrm{e}$ \\
\hline Sweet Chocolate & $69.3 \mathrm{ab}$ & $7.22 \mathrm{a}-\mathrm{f}$ & $12.3 \mathrm{bc}$ & $1.02 \mathrm{c}-\mathrm{e}$ \\
\hline Ace & $66.3 \mathrm{a}-\mathrm{c}$ & $9.13 \mathrm{a}-\mathrm{c}$ & $19.7 \mathrm{a}$ & $2.10 \mathrm{ab}$ \\
\hline North Star & $58.7 \mathrm{a}-\mathrm{d}$ & $9.01 \mathrm{a}-\mathrm{e}$ & $6.7 \mathrm{~cd}$ & $0.86 \mathrm{de}$ \\
\hline Vivaldi & $48.7 \mathrm{a}-\mathrm{e}$ & $9.58 \mathrm{ab}$ & $9.0 \mathrm{~cd}$ & $1.57 \mathrm{a}-\mathrm{e}$ \\
\hline Telestar & $46.7 \mathrm{a}-\mathrm{e}$ & $5.46 \mathrm{~b}-\mathrm{g}$ & $8.7 \mathrm{~cd}$ & $1.35 \mathrm{~b}-\mathrm{e}$ \\
\hline Lady Bell & $41.0 \mathrm{~b}-\mathrm{e}$ & $7.52 \mathrm{a}-\mathrm{e}$ & $17.7 \mathrm{a}-\mathrm{c}$ & $2.42 \mathrm{a}$ \\
\hline Alliance & $37.0 \mathrm{~b}-\mathrm{e}$ & $5.48 \mathrm{~b}-\mathrm{g}$ & $13.0 \mathrm{a}-\mathrm{c}$ & $1.92 \mathrm{a}-\mathrm{c}$ \\
\hline Yankee Bell & $35.3 \mathrm{~b}-\mathrm{e}$ & $5.49 \mathrm{~b}-\mathrm{g}$ & $7.0 \mathrm{~cd}$ & $0.79 \mathrm{e}$ \\
\hline Socrates & $30.0 \mathrm{~b}-\mathrm{e}$ & $6.15 \mathrm{~b}-\mathrm{g}$ & $18.3 \mathrm{a}-\mathrm{c}$ & $2.42 \mathrm{a}$ \\
\hline King Arthur & $25.0 \mathrm{c}-\mathrm{e}$ & $5.33 \mathrm{~b}-\mathrm{g}$ & $4.3 \mathrm{~d}$ & $0.78 \mathrm{e}$ \\
\hline Double-Up & $23.7 c-\mathrm{e}$ & $4.76 \mathrm{~b}-\mathrm{g}$ & $4.7 \mathrm{~d}$ & $0.82 \mathrm{e}$ \\
\hline Excel & $22.0 \mathrm{de}$ & $4.28 \mathrm{~b}-\mathrm{g}$ & $8.7 \mathrm{~cd}$ & $1.22 \mathrm{~b}-\mathrm{e}$ \\
\hline Orion & $22.0 \mathrm{de}$ & $4.23 \mathrm{~b}-\mathrm{g}$ & $4.0 \mathrm{~d}$ & $0.69 \mathrm{e}$ \\
\hline Red Knight & $18.3 \mathrm{de}$ & $3.50 \mathrm{~d}-\mathrm{g}$ & $11.7 \mathrm{bc}$ & $1.80 \mathrm{a}-\mathrm{c}$ \\
\hline Revolution & $18.3 \mathrm{de}$ & $3.95 \mathrm{c}-\mathrm{g}$ & $10.7 \mathrm{~cd}$ & $1.76 \mathrm{a}-\mathrm{d}$ \\
\hline Boyton Bell & $17.7 \mathrm{ce}$ & $3.34 \mathrm{e}-\mathrm{g}$ & $7.3 \mathrm{~cd}$ & $1.08 \mathrm{c}-\mathrm{e}$ \\
\hline Brigadier & $12.7 \mathrm{e}$ & $2.38 \mathrm{e}-\mathrm{g}$ & $7.0 \mathrm{~cd}$ & $1.07 \mathrm{c}-\mathrm{e}$ \\
\hline Aristotle X3R & $10.0 \mathrm{e}$ & $1.91 \mathrm{fg}^{\circ}$ & $7.7 \mathrm{~cd}$ & $1.32 \mathrm{~b}-\mathrm{e}$ \\
\hline Patriot & $6.3 \mathrm{e}$ & $1.37 \mathrm{~g}$ & $9.7 \mathrm{~cd}$ & $1.22 \mathrm{c}-\mathrm{e}$ \\
\hline $\operatorname{LSD}(P=0.05)$ & 43.7 & $5.55^{\circ}$ & 6.9 & 0.93 \\
\hline
\end{tabular}

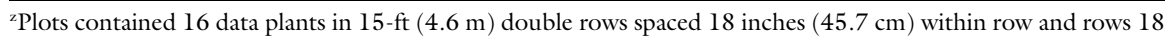
inches apart. Double rows were $6 \mathrm{ft}(1.8 \mathrm{~m})$ apart.

${ }^{\mathrm{y}} 1 \mathrm{~kg}=2.2046 \mathrm{lb}$.

${ }^{\mathrm{x}} \mathrm{LSD}$ at $P=0.05$; means in the same year within a column not followed with the same letter are significantly different.

${ }^{\text {ss Nonsignificant. }}$
'Northstar' and 'Telestar' were the most promising for yield, with both performing among the top six cultivars in 2005 .

The number and weight of cull fruit did not differ significantly between cultivars evaluated in 2003 and 2004. In 2005, 'King Arthur', 'Double-Up', and 'Orion' had significantly fewer cull fruit than some cultivars, while 'Ace', 'Lady Bell', 'Socrates', and 'Alliance' produced more cull fruit by weight and number than other cultivars. However, when taken as a percentage of total yield, cull rates were not highly variable, ranging from $15 \%$ to $23 \%$. The defects most often resulting in culls were sun scald followed by misshapen fruit and small fruit.

Fruit quality characteristics, including individual fruit weight, number of lobes per fruit, fruit shape, and wall thickness, can greatly affect market value and acceptance. Heavy individual fruit with three to four lobes, a blocky (not pointed) shape, and thick walls are preferred, will meet greater market acceptance, and command higher prices.

Among the eight cultivars evaluated in all 3 years of the trial, 'Ace' and 'New Ace', the highest ranked cultivars for yield, were consistently ranked lowest for fruit individual fruit weight (Table 4). 'Brigadier' and 'Vivaldi' consistently had the largest fruit by weight. In 2003 and 2005, the cultivars King Arthur, Socrates, and Patriot each had heavy individual fruit weights, but all ranked in the middle of the range in 2004 . 'Double-Up' was among the heaviestfruited cultivars in 2005 , but was ranked among the smaller fruit in 2003 and 2004.

Of the cultivars that were evaluated in 2 of the 3 years of the trial, none were consistently among the heaviest fruit, although most ranked in the upper half of the range. 'Sweet Chocolate', which, like 'Ace' and 'New Ace' had relatively high yields (number of fruit), also had low individual fruit weight.

For best market quality, bell peppers should average between three and four lobes per fruit. In this trial, nearly all cultivars consistently averaged greater than three lobes and would therefore meet market standards for this characteristic (Table 4). The notable exception to this was 
VARIETY TRIALS

Table 4. Mean fruit weight, number of lobes, and fruit size of bell peppers grown 2003-2005 at University of Maine, Highmoor Farm, in Monmouth. ${ }^{\mathrm{z}}$

\begin{tabular}{|c|c|c|c|c|c|}
\hline Cultivar & Fruit wt $(g)^{y}$ & Lobes (no.) & Fruit length $(\mathrm{cm})^{\mathrm{y}}$ & Fruit width $(\mathrm{cm})$ & Fruit thickness $(\mathrm{mm})^{\mathrm{y}}$ \\
\hline & \multicolumn{5}{|c|}{2003} \\
\hline Ace & $150.5 \mathrm{e}$ & 2.8 & $9.7 \mathrm{~d}$ & $8.4 \mathrm{~d}$ & $5.3 \mathrm{e}$ \\
\hline Aristotle X3R & $188.0 \mathrm{~b}-\mathrm{e}$ & 3.5 & $8.9 \mathrm{~d}$ & $9.2 \mathrm{a}-\mathrm{d}$ & $7.8 \mathrm{ab}$ \\
\hline Double-Up & $152.6 \mathrm{e}$ & 3.5 & $9.8 \mathrm{~cd}$ & $8.3 \mathrm{~d}$ & $7.3 \mathrm{a}-\mathrm{d}$ \\
\hline Early Sunsation & $195.4 \mathrm{~b}-\mathrm{e}$ & 3.4 & $9.8 \mathrm{~cd}$ & $9.5 \mathrm{a}-\mathrm{c}$ & $6.9 \mathrm{~b}-\mathrm{d}$ \\
\hline Ironsides & $204.0 \mathrm{~b}-\mathrm{e}$ & 3.0 & $10.2 \mathrm{~cd}$ & $8.4 \mathrm{~d}$ & $6.3 \mathrm{c}-\mathrm{e}$ \\
\hline King Arthur & $243.1 \mathrm{a}-\mathrm{d}$ & 3.3 & $10.0 \mathrm{~cd}$ & $8.7 \mathrm{~b}-\mathrm{d}$ & $7.2 \mathrm{a}-\mathrm{d}$ \\
\hline New Ace & $157.3 \mathrm{de}$ & 3.2 & $9.6 \mathrm{~d}$ & $8.6 \mathrm{~b}-\mathrm{d}$ & $5.9 \mathrm{de}$ \\
\hline Olympus & $253.2 \mathrm{a}-\mathrm{d}$ & 3.3 & $9.8 \mathrm{~cd}$ & $8.3 \mathrm{~d}$ & $7.4 \mathrm{a}-\mathrm{c}$ \\
\hline Patriot & $236.4 \mathrm{a}-\mathrm{d}$ & 3.8 & $10.1 \mathrm{~cd}$ & $9.9 \mathrm{a}$ & $8.4 \mathrm{a}$ \\
\hline Queen & $182.0 \mathrm{c}-\mathrm{e}$ & 3.4 & $9.4 \mathrm{~d}$ & $8.5 \mathrm{~cd}$ & $7.1 \mathrm{a}-\mathrm{d}$ \\
\hline & \multicolumn{5}{|c|}{2004} \\
\hline Ace & $73.3 \mathrm{e}$ & $4.0 \mathrm{ab}$ & $9.1 \mathrm{~b}-\mathrm{d}$ & $7.7 \mathrm{~d}$ & $5.7 \mathrm{ef}$ \\
\hline Boyton Bell & $118.4 \mathrm{c}-\mathrm{e}$ & $3.2 \mathrm{c}-\mathrm{e}$ & $7.5 \mathrm{e}$ & $7.6 \mathrm{~d}$ & $6.4 \mathrm{~d}-\mathrm{f}$ \\
\hline Brigadier & $192.3 \mathrm{ab}$ & $4.0 \mathrm{ab}$ & $8.4 \mathrm{c}-\mathrm{e}$ & $8.8 \mathrm{~b}-\mathrm{d}$ & $6.6 \mathrm{c}-\mathrm{e}$ \\
\hline Double-Up & $105.0 \mathrm{c}-\mathrm{e}$ & $3.4 \mathrm{~b}-\mathrm{e}$ & $8.1 \mathrm{de}$ & $7.8 \mathrm{~d}$ & $6.1 \mathrm{ef}$ \\
\hline Early Sunsation & $130.5 \mathrm{~b}-\mathrm{e}$ & $3.4 \mathrm{~b}-\mathrm{e}$ & $9.0 \mathrm{c}-\mathrm{e}$ & $7.8 \mathrm{~d}$ & 5.9 ef \\
\hline Karma & $141.9 \mathrm{~b}-\mathrm{e}$ & $3.2 \mathrm{c}-\mathrm{e}$ & $8.3 \mathrm{de}$ & $7.7 \mathrm{~d}$ & $6.3 \mathrm{~d}-\mathrm{f}$ \\
\hline King Arthur & $147.1 \mathrm{~b}-\mathrm{d}$ & $3.0 \mathrm{de}$ & $7.5 \mathrm{e}$ & $8.6 \mathrm{~cd}$ & $6.3 \mathrm{~d}-\mathrm{f}$ \\
\hline Lady Bell & $100.7 \mathrm{c}-\mathrm{e}$ & $3.2 \mathrm{c}-\mathrm{e}$ & $9.9 \mathrm{a}-\mathrm{c}$ & $8.2 \mathrm{~d}$ & $7.2 \mathrm{~b}-\mathrm{d}$ \\
\hline New Ace & $90.7 \mathrm{de}$ & $3.6 \mathrm{~b}-\mathrm{d}$ & $9.2 \mathrm{~b}-\mathrm{d}$ & $8.2 \mathrm{~d}$ & $5.6 \mathrm{f}$ \\
\hline Patriot & $103.6 \mathrm{c}-\mathrm{e}$ & $4.0 \mathrm{ab}$ & $8.6 \mathrm{c}-\mathrm{e}$ & $10.0 \mathrm{ab}$ & $7.9 \mathrm{ab}$ \\
\hline Red Knight & $135.9 \mathrm{~b}-\mathrm{e}$ & $4.4 \mathrm{a}$ & $8.4 \mathrm{c}-\mathrm{e}$ & $10.2 \mathrm{ab}$ & $7.8 \mathrm{ab}$ \\
\hline Alliance & $168.7 \mathrm{a}-\mathrm{d}$ & $3.6 \mathrm{~b}-\mathrm{d}$ & $9.1 \mathrm{c}-\mathrm{f}$ & $9.0 \mathrm{a}$ & $6.4 \mathrm{a}-\mathrm{e}$ \\
\hline Aristotle X3R & $199.9 \mathrm{ab}$ & $3.5 \mathrm{~b}-\mathrm{e}$ & $9.1 \mathrm{c}-\mathrm{f}$ & $9.0 \mathrm{a}$ & $6.6 \mathrm{a}-\mathrm{d}$ \\
\hline Boyton Bell & $189.3 \mathrm{a}-\mathrm{c}$ & $3.0 \mathrm{ef}$ & $9.5 \mathrm{~b}-\mathrm{e}$ & $7.9 \mathrm{~b}-\mathrm{f}$ & $6.5 \mathrm{a}-\mathrm{e}$ \\
\hline Brigadier & $186.7 \mathrm{a}-\mathrm{c}$ & $3.4 \mathrm{~b}-\mathrm{e}$ & $9.0 \mathrm{c}-\mathrm{g}$ & $8.4 \mathrm{a}-\mathrm{d}$ & $6.6 \mathrm{a}-\mathrm{d}$ \\
\hline Double-Up & $193.3 \mathrm{a}-\mathrm{c}$ & $3.3 \mathrm{c}-\mathrm{f}$ & $9.2 \mathrm{~b}-\mathrm{f}$ & $7.8 \mathrm{c}-\mathrm{f}$ & $6.6 \mathrm{a}-\mathrm{d}$ \\
\hline Excel & $192.4 \mathrm{a}-\mathrm{c}$ & $4.3 \mathrm{a}$ & $9.1 \mathrm{c}-\mathrm{f}$ & $8.2 \mathrm{~b}-\mathrm{e}$ & $6.4 \mathrm{a}-\mathrm{e}$ \\
\hline King Arthur & $210.9 \mathrm{ab}$ & $3.3 \mathrm{c}-\mathrm{f}$ & $9.0 \mathrm{c}-\mathrm{g}$ & $8.6 \mathrm{ab}$ & $7.1 \mathrm{ab}$ \\
\hline Lady Bell & $188.7 \mathrm{a}-\mathrm{c}$ & $3.2 \mathrm{c}-\mathrm{f}$ & $10.3 \mathrm{~b}$ & $7.9 \mathrm{~b}-\mathrm{f}$ & $5.9 \mathrm{c}-\mathrm{g}$ \\
\hline New Ace & $140.6 \mathrm{c}-\mathrm{e}$ & $3.4 \mathrm{~b}-\mathrm{e}$ & $10.0 \mathrm{bc}$ & $7.4 \mathrm{f}$ & $5.2 \mathrm{~g}$ \\
\hline North Star & $166.3 \mathrm{a}-\mathrm{d}$ & $3.3 \mathrm{c}-\mathrm{f}$ & $9.8 \mathrm{~b}-\mathrm{d}$ & $8.5 \mathrm{a}-\mathrm{c}$ & $6.8 \mathrm{a}-\mathrm{c}$ \\
\hline Orion & $216.4 \mathrm{a}$ & $3.6 \mathrm{ab}$ & $8.4 \mathrm{e}-\mathrm{g}$ & $8.0 \mathrm{~b}-\mathrm{f}$ & $5.8 \mathrm{~d}-\mathrm{g}$ \\
\hline Patriot & $222.2 \mathrm{a}$ & $3.7 \mathrm{bc}$ & $8.8 \mathrm{~d}-\mathrm{g}$ & $9.0 \mathrm{a}$ & $7.1 \mathrm{a}$ \\
\hline Red Knight & $196.2 \mathrm{a}-\mathrm{c}$ & $3.2 \mathrm{c}-\mathrm{f}$ & $9.5 \mathrm{~b}-\mathrm{e}$ & $8.3 \mathrm{a}-\mathrm{d}$ & $6.8 \mathrm{a}-\mathrm{c}$ \\
\hline Revolution & $213.8 \mathrm{a}$ & $3.6 \mathrm{~b}-\mathrm{d}$ & $8.2 \mathrm{fg}$ & $9.0 \mathrm{a}$ & $6.1 \mathrm{c}-\mathrm{g}$ \\
\hline Socrates & $200.5 \mathrm{ab}$ & $3.4 \mathrm{~b}-\mathrm{e}$ & $8.0 \mathrm{~g}$ & $7.5 \mathrm{ef}$ & $6.2 \mathrm{~b}-\mathrm{f}$ \\
\hline Sweet Chocolate & $120.1 \mathrm{de}$ & $3.1 \mathrm{~d}-\mathrm{f}$ & $9.8 \mathrm{~b}-\mathrm{d}$ & $5.9 \mathrm{~g}$ & $5.6 \mathrm{e}-\mathrm{g}$ \\
\hline Telstar & $167.6 \mathrm{a}-\mathrm{d}$ & $3.4 \mathrm{~b}-\mathrm{e}$ & $9.3 \mathrm{~b}-\mathrm{f}$ & $8.4 \mathrm{a}-\mathrm{d}$ & $7.2 \mathrm{a}$ \\
\hline Vivaldi & $199.2 \mathrm{a}-\mathrm{c}$ & $3.7 \mathrm{bc}$ & $12.5 \mathrm{a}$ & $8.2 \mathrm{~b}-\mathrm{c}$ & $6.8 \mathrm{a}-\mathrm{c}$ \\
\hline Yankee Bell & $154.0 \mathrm{~b}-\mathrm{d}$ & $3.3 c-f$ & $9.4 \mathrm{~b}-\mathrm{e}$ & $8.1 \mathrm{~b}-\mathrm{f}$ & $6.3 \mathrm{a}-\mathrm{f}$ \\
\hline $\operatorname{LSD}(P=0.05)$ & 59.0 & 0.6 & 1.1 & 0.8 & 0.9 \\
\hline
\end{tabular}

${ }^{2}$ Means of averages of measurements of 10 randomly selected fruit.

${ }^{\mathrm{y}} \mathrm{l} \mathrm{g}=0.0353 \mathrm{oz}, 1 \mathrm{~cm}=0.3937$ inch, $1 \mathrm{~mm}=0.0394$ inch.

${ }^{x}$ LSD at $P=0.05$; means in the same year within a column not followed with the same letter are significantly different.

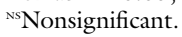


'Ace', which, despite being consistently among the highest yielding cultivars, produced fruit that averaged less than three lobes in 2 of the 3 years $(2003,2005)$.

Fruit size, as measured by length and width (Table 4) appeared to be within the range reported in other trials (Greenland et al., 2005; Rowell et al., 2001; Zandstra and Squire, 2001, 2004). 'Vivaldi' consistently had the largest fruit size. Other cultivars with large-sized fruit included 'Socrates' and 'Heritage' (in 2003 only). The highest overall yielding cultivars, including 'Ace', 'New Ace', and 'Sweet Chocolate', generally produced significantly smaller fruit compared with other cultivars, especially in terms of fruit weight and width.

Fruit wall thickness varied significantly among the cultivars evaluated (Table 4). 'Patriot' and 'Vivaldi' consistently had the thickest walls of any cultivar in the trial. 'Aristotle' (in 2003 and 2005), 'Heritage' (in 2003), and 'Telestar' (in 2005) also ranked highly for wall thickness, but were only evaluated over one or two seasons. 'Brigadier' and 'King Arthur' both ranked among the thickest walled cultivars in 2 of the 3 years they were evaluated. 'Ace' and 'New Ace' had the thinnest walls of any cultivars in the trial.

The short growing season and variable temperatures characteristic of Maine's climate clearly limits the production of high quality green bell peppers with the cultivars available today. Of the 27 cultivars of peppers evaluated in this 3-year study, few could produce even one-quarter of the yield reported in other regions (Greenland et al., 2005; Rowell et al., 2001; Zandstra and Squire, 2001, 2003 , 2004). Only two cultivars,
'Ace' and 'New Ace', produced yields that would seem high enough to generate reasonable profit (slightly over $6000 \mathrm{lb} /$ acre). Both of the cultivars, however, were characterized by small fruit size, thin walls, and fewer than three lobes. 'Sweet Chocolate' showed promising yield, but it tended to be light weight with thin walls and was relatively long and slender in shape. Furthermore, the mature color of the fruit is deep brown, which some markets may find undesirable.

'Ace' and 'New Ace', although highest yielding in this study, are generally not suitable cultivars for most wholesale markets because of their small size, thin walls, and high percentage of two- and three-lobed fruit. However, in northern New England most commercially grown peppers are marketed through local direct marketing channels such as roadside stands and farmer's markets. Consumers using these markets are accustomed to these cultivars, including their faults, and will generally accept them. However, there remains an unfulfilled demand for local highquality, large, blocky bell peppers for the regional wholesale buyers who supply local supermarkets (W. Wedge, personal communication.) As a result, many Maine growers now choose to grow lower-yielding cultivars such as 'King Arthur' (unpublished survey results) because of their higher commercial market acceptance.

None of the cultivars evaluated in this trial offered completely acceptable traits for either yield or fruit quality. Improved bell pepper cultivars, better adapted to short growing seasons and more tolerant of seasonal temperature fluctuation, could greatly improve the potential for this crop in northern growing regions and enhance the profitability of pepper production for local wholesale and retail markets.

\section{Literature cited}

Greenland, R., L. Besemann, and $\mathrm{H}$. Eslinger. 2005. Pepper hybrid performance trial. 2 Aug. 2006. <http://www. ag.ndsu.nodak.edu/oakes/2005Report/ pppt05rpt.htm>.

Maynard, D.N. and G.J. Hotchmuth. 1997. Knott's handbook for vegetable growers. 4th ed. Wiley, New York.

Rowell, B., R.T. Jones, W. Nesmith, A. Satanek, and J.C. Snyder. 2001. Bacterial spot resistance, yield, and quality of bell and specialty peppers. HortTechnology 11(4):648-657.

U.S. Department of Agriculture. 2004. 2002 Census of agriculture, Vol. 1, Chapter 2: New England state level, Tables 10 and 28. 2 Aug. 2006. <http://www.nass. usda.gov/census/census02/volumel/ newengland/index2.htm $>$.

Wells, O.S. and J.B. Loy. 1985. Intensive vegetable productions with row covers. HortScience 20(5):822-826.

Wien, C.H. 1997. Peppers, p. 259-293. In: H.C. Wien (ed.). The physiology of vegetable crops. CAB Intl., New York.

Zandstra, J.W. and R.C. Squire. 2001. Bacterial spot resistant pepper cultivar evaluation. 2 Aug. 2006. <http://www. ridgetownc.on.ca/research/documents/ zandstra_pep01.PDF $>$.

Zandstra, J.W. and R.C. Squire. 2003. Bacterial spot resistant pepper cultivar evaluation. 2 Aug. 2006. <http://www. ridgetownc.on.ca/research/documents/ zandstra_2003_BLS_pepper.PDF>.

Zandstra, J.W. and R.C. Squire. 2004. Bacterial spot resistant pepper cultivar evaluation. 2 Aug. 2006. <http://www. ridgetownc.on.ca/research/documents/ zandstra_2004_bls_pepper.PDF>. 